\title{
ResearchOnline@JCU
}

This is the author-created version of the following work:

Greenhalgh, Garry, Alexander, Kim S., Larson, Silva, Thammavong,

Phommath, Sacklokham, Silinthone, Thephavanh, Manithaythip, Sinavong,

Phonevilay, Moglia, Magnus, Perez, Pascal, and Case, Peter (2019)

Transdisciplinary agricultural research in Lao PDR. Journal of Rural Studies, 72

pp. 216-227.

Access to this file is available from:

https://researchonline.jcu.edu.au/60761/

Published Version: [〔 2019 Published by Elsevier Ltd.] Accepted Version: (c) 2019.

This manuscript version is made available under the CC-BY-NC-ND 4.0 license http://creativecommons.org/licenses/by-nc-nd/4.0/

Please refer to the original source for the final version of this work: 


\section{Transdisciplinary agricultural research in Lao PDR}

Garry Greenhalgh ${ }^{a}$, Kim S. Alexandera , Silva Larson ${ }^{b}$, Phommath Thammavong $^{c}$, Silinthone, Sacklokham ${ }^{c}$, Manithaythip Thephavanh ${ }^{d}$, Phonevilay Sinavong $^{d}$, Magnus Moglia ${ }^{e}$, Pascal Perez $^{f}$ Peter Case ${ }^{a, g}$

a James Cook University, bUniversity of Sunshine Coast, ' National University of Laos, ${ }^{\mathrm{d}}$ National Agricultural and Forestry Research Institute, ${ }^{e}$ Commonwealth Scientific and Industrial Research Organisation (CSIRO), ${ }^{f}$ Hema Consulting, gUniversity of the West of England (UWE), Bristol

Corresponding author: Kim S. Alexander, College of Business, Law and Governance, Division of Tropical Environments and Societies, James Cook University Townsville, Australia. Email: kim.alexander56@gmail.com

\section{Abstract}

Transdisciplinary research focussing on improving smallholder farmers' uptake of technological innovations enables the integration of knowledge systems and the co-design and delivery of creative solutions. In this paper, we illustrate how scientific research can be mobilized within professionally facilitated change management workshops to engage a broad range of stakeholders and co-create knowledge in a rural development context. Multi-institutional, multi-disciplinary and multi-national stakeholders have contributed to finding innovative solutions to challenges experienced by smallholder farmers. By combining different worldviews we were able to assess research priorities, define problems and determine research options based on new hybrid knowledge systems. The outcome of this transdisciplinary process was the co-creation of a Research Discussion Tool and identification of 9 thematic areas which, in combination, enabled obstacles to technology uptake to be overcome and for smallholder farmers to benefit from research-based innovations. The process involved assisting Lao national researchers and extension agents to co-develop solutions, strategies and methods to improve technology uptake by farmers in the lowlands of southern Lao PDR using a series of change management interventions. A complex ecology of factors involving farmers' decision drivers/motivations and farmers' decision enablers within farmers' production systems influence technology uptake. The relative importance of each factor is dependent on the specific technology that 
is being introduced. Hence, projects that introduce new technologies struggle to address all relevant factors and often do not have the ability to deal with the complex array of factors that are at play. The process of co-construction embeds local knowledge that becomes accessible to projects. The approach we document in this paper also has the potential to harness collaborative exchanges with other projects in similar geographical regions.

\section{Keywords: adoption; technology; knowledge; international development; rural development} agriculture; innovation.

\section{Introduction}

Many well-intentioned international agricultural programs have been less effective than forecast, often through an inability to fully understand the realities and priorities of small-scale farmers, particularly those cultivating in resource-poor areas (Collinson, 2000, Thornton et al., 2017, Wossen et al., 2017). Orr (2012) supports this notion by suggesting that the socioeconomic, political and institutional contexts within which small-scale farmers operate have been poorly understood.

Originally, notions of domination and economic gain, progress and welfarism arose from the age of imperialism (1860-1945) (Gardner and Lewis 1996, Potter et al., 2008). Advancing agricultural production has continued to be the remit of developed nations. The Green Revolution initiated international research and technology transfers (ToT) during 1950-1960s, aimed at increasing agricultural production worldwide (Stevenson et al. 2013). With the advent and development of new cultivars and practices to increase agricultural production, an exchange of knowledge between smallscale farmers and international agencies was required (Stevenson et al., 2013). Knowledge exchange occurred through field research and national agricultural research and extension systems using a pipeline approach, where the farmer was assumed to be a passive recipient of new technologies and practices (Douthwaite et al., 2017, Sumberg et al., 2013). Scientific knowledge was expected to trickle down and technology transfer used to leverage changed behaviours (Latour, 1998). These processes were informed by government policies and agricultural research projects and devolved through statebased extension bodies. The role of extension agents was to disseminate information and transfer new technologies to farmers, aiming to increase agricultural productivity (Feder et al., 1985). Hence agricultural extension was seen as a 'boundary institution'; an interface providing a dissemination mechanism between agricultural science and farmers (Cash, 2000). 
The 1980's saw new approaches to inclusion, participation and learning in rural development. Chambers (1983) and Pretty (1995) provide examples of participatory practices that enabled farming systems researchers to engage more effectively with farming communities using action research methods (Sumberg and Thompson, 2012). Jiggins (2000) claims that participatory methods, taking a gender-inclusive farming system and extension approach provided a richer, more deeply contextualized understanding of the farmers' circumstance and how to build the capacity of farmers. Participatory methods were often used to establish convergence, consistency and agreement, increasing confidence in the appropriateness of specific technical solutions (Farrington and Martin, 1988). Participatory methods were also useful in illuminating challenging assumptions and encouraging further engagement. Not surprisingly, participatory methods revealed barriers and constraints for smallholder farmers that could outweigh the projected opportunities of introduced technical solutions (Jiggins, 2000). To achieve technology uptake, the complexity and variability of agro-ecological conditions, the biomass and the diverse criteria by which farmers assess a new technology are all of critical importance (Farrington and Martin, 1988).

To accommodate the need for more holistic approaches to support technology uptake and acknowledging the web of interacting providers that support agriculture, participatory farming systems research broadened to multi-disciplinary agricultural research. The sustainable livelihoods approach was used to determine farmers' livelihood strategies, land use decisions and contextual forms of assets and capital (natural resources, human capital, physical and financial capital, community-owned resources and political capital) (Scoones, 2009). Resource assets and capital significantly influenced household production and land use (Pretty, 1998, Vosti and Witcover, 1996). Scoones (2009) developed a checklist of issues for exploring key connections and linkages between the various elements within the framework. Rather than a precise measurement, the heuristic tool provided an indepth consideration and qualitative discussions of key issues.

To understand more broadly the implications of farming systems changes, socio-technical systems considered innovation niches within which movements from one state to another occur, influenced by the regimes, or rules and institutions, and the landscape in which the social and technological change occurs (Geels and Schot, 2007, Geels and Schot, 2011). To inform a systems perspective, participation, collaboration and knowledge exchange were required to explore diverse visions and 
standpoints (Pereira et al., 2015, Pereira et al., 2016). Innovation is not straight forward, particularly within centrally controlled agricultural economies (Friederichsen et al., 2013).

The emergence of the Agricultural Innovation Systems framework (AIS) (Hall et al., 2006, Klerkx and Nettle, 2013, Lamprinopoulou et al., 2014, World Bank, 2012) broadened the definition of the agricultural system and further established the need for reflexive, learning interactions between actors. The AIS framework has been primarily used to understand how agrarian production is influenced by complex interactions between public, private, and civil society actors, in rapidly changing market and policy regimes (Spielman et al., 2009) and how institutional dynamics across a variety of levels influence agricultural development (Basu and Leeuwis, 2012). Understanding institutional structures (e.g., from government policy through to local cultural norms) across institutional settings, can highlight many of the constraints and opportunities for change (Biggs, 2007; Nederlof et al., 2007). More recently, Douthwaite and Hoffecker (2017) argue that to promote agricultural change, agricultural research for development (AR4D) initiatives require more systemic, experimental, iterative, and participatory interventions if successful technology uptake is to occur. Notably, these methods of envisaging and formulating models of agricultural change, development and extension have incorporated farmers' knowledge, farmers' participation, and farmers' needs while cognizant of prevailing political and socio-cultural contexts (Dias et al., 2019, Friederichsen et al., 2013, Morris et al., 2017).

Vogel et al. (2007) suggest that different worldviews, positions and knowledge when engaged in negotiations of research priorities, problem definitions and research options give rise to new hybrid knowledge systems. Scoones et al. (2018) claim that co-constructed new knowledges are essential for transdisciplinarity - the crossing of disciplinary boundaries to create a more holistic approach, involving creative solutions, stakeholder involvement and ensuring outcomes of socially responsible science (Bernstein, 2015). Transdisciplinary research fosters the integration of multiple disciplines and knowledge systems and requires a broad range of stakeholders beyond academia. The process involves reflecting on real-world problems and combines expert facilitation to enable co-designed research that leads to impact (Blythe et al., 2017, Davila et al., 2018, van Kerkhoff and Lebel, 2015). Jasanoff (2004) believes that co-constructed new knowledges are a combination of new ways of thinking about problems, manifesting solutions involving new ways of tackling problems. 
In this paper we report on an integrative and deliberative process of engagement with multiple stakeholders (farmers, private sector actors, government agencies and researchers) used to determine the supporting conditions required to maximize the likelihood of farmers' technology uptake. The process involved assisting Lao national researchers and extension agents to co-develop solutions, strategies and methods to improve technology uptake by farmers in the lowlands of southern Lao PDR using a change management process (Greenhalgh and Alexander, 2017, Stein and Valters, 2012, Vogel, 2012). Collectively, local knowledge from stakeholders and qualitative and quantitative research data have been synthesized into a Research Discussion Tool (RDT). In a deliberative, transdisciplinary process, the data from multidisciplinary research methods has been merged with local knowledge during workshops designed to co-construct new knowledge. Based on consensus, collective actions were determined in the key areas that were found to influence technology adoption.

Specifically, this paper intends to make four contributions to academic literature. Firstly, we demonstrate that this transdisciplinary approach can be an effective method when investigating how to boost the uptake of agricultural technology by smallholder farmers. Secondly, change management practices developed and applied in the private sector (of the western world), when adapted are powerful tools to generate ownership and leadership within a rural development research context. Thirdly, we have designed an innovative tool to assist stakeholders understand more about the introduced technology and to identify suitable villages (and hence farmers) likely to adopt the new technology. Fourthly, we describe 9 themes that, together with the RDT, represent a comprehensive, end to end, solution to the adoption of new technologies. We believe this comprehensive end-to-end solution is generalizable to other developing countries. It is context specific, we contend but not culturally specific.

The article is structured as follows. We begin with a brief overview of agricultural sector issues in Lao PDR and, in particular, the Government's desire to transition smallholder farmers away from subsistence and towards more commercial production. We then introduce the transdisciplinary process that we designed and implemented; one of the core activities of our research project. We describe the 'Solution Space' workshop that was convened and how this generated key insights and understanding of the factors that influence technology adoption in the Lao smallholder context. We 
illustrate the approaches used to co-construct the Research Discussion Tool - a transdisciplinary instrument - to increase the likelihood of technology uptake. We subsequently explore the key thematic areas that influence technology adoption. An outcome of the workshop has been the formulation of a comprehensive solution to support technology adoption. Finally, we conclude by reflecting on the implications for adoption research studies and for Lao government agricultural policies.

\section{The agricultural sector in Lao PDR}

The Lao People's Democratic Republic (Lao PDR) is considered by the United Nations to be one of the 'Least Developed' countries in the world, based on figures reflecting national income, human assets and economic vulnerability (United Nations, 2018;2019, FAO, 2019). Recent Lao government policies have encouraged industrialization, intensive agricultural production and market integration to improve their ranking in the Least Developed Category (Cook, 2006, FAO, 2019). Furthermore, the country's economic growth has been reported at a five year average of over $7.9 \%$ and GDP is expected to continue to rise (Ministry of Planning and Investment, 2016 p4). Yet while poverty has been declining, household consumption continues to lag, particularly in rural areas and for lower socio-economic groups, more often for ethnic minorities (Pimhidzai et al., 2014).

Improvement of rural livelihoods is an important policy priority of the Lao Government as up to threequarters of Lao PDR's labour force work within the agricultural sector. FAO (2019) estimates that 80 percent of the rural population is represented by smallholder farmers, dependent on rice-based agriculture and livestock, producing on arable land of two to three hectares (Alexander et al., 2010, Alexander and Larson, 2016, Ministry of Agriculture and Forestry (MAF), 2010). Over the years Land Use Planning and Land Allocation (LUP/LA) programs in Lao PDR have been introduced with the area of land allocated to individual households based on each household's available labour and resources (Thongphanh, 2004). Philp et al. (2019) argue that smallholder farming on infertile, poorly structured soils results in marginal land productivity and low labour productivity. These farmers often face risks due to climate variability in the form of typhoons, floods and droughts and are constantly threatened by rodent and pest attacks, and animal disease epidemics (FAO, 2019, Roth and Grunbuhel, 2012). Hence, while farmers are generally considering opportunities to increase production and income 
through more intensive farming activities, many prefer out-migration and wage opportunities (Alexander et al., 2018, Manivong et al., 2014).

Lao government agricultural strategies and policies aim to support more intensive productivity in key areas, particularly in the more fertile plains in Southern Lao PDR, projecting a gradual transition from subsistence to commercial smallholder production (MAF, 2010). In response, there has been an expansion of commercial plantation crops best suited to agro-processing for the export market including coffee, cassava, maize and sugarcane, sweet potato and industrial tree crops (such as rubber, eucalyptus and acacia) (FAO, 2019, Ministry of Planning and Investment, 2016). Lao PDR contributes $0.2 \%$ of the world rice exports at an estimated value of US $\$ 36.6$ million per annum (Workman, 2019) and policies are in place to further increase rice exports (MAF, 2010). Livestock production has also become increasingly commercialized in recent years (Ministry of Planning and Investment, 2016, Stür and Gray, 2014). FAO (2019) calculates that 33\% of farmers are primarily selling their produce, largely to local traders (FAO, 2019).

Our research is framed around the 'new technologies and agricultural practices' that have been previously introduced to smallholder farmers in southern Lao PDR (Larson and Alexander 2016). Our term 'technologies' encompasses any new technology, method or practice change including: drought resilient rice and crop varieties; use of appropriate inputs (e.g. varieties, fertilizer, time of planting, etc.); direct seeding of rice to reduce the labour requirement for planting; weed management; efficient irrigated water use; and more appropriate dry-season irrigated crops. Cash crops such as maize and grain legumes (mung bean and/or soybean) have also been introduced to sites with reliable irrigation. Extension systems have been targeted to scale out knowledge-based technologies such as new rice varieties and livestock and water management techniques. Projects have also been dedicated to developing effective and supportive agricultural policies for rice-based farming systems.

\section{Research efforts to understand technology uptake}

Globally, there has been significant agricultural research effort dedicated to understanding technology adoption (Alcon et al., 2014, Douthwaite et al., 2001, Feder et al., 1985, German et al., 2006, Ghadim and Pannell, 1999, Hailu et al., 2014, Knowler, 2015, Knowler \& Bradshaw, 2007, Pannell et al., 2006, World Bank, 2012). Many researchers have explored factors that may improve the chance of farmers' adoption of new technologies (Alexander et al., 2018; Ayele et al., 2012, Clarke et al., 2016, Gilles et 
al., 2013, Griliches, 1957, Hogset, 2005, Kebede, 1992, Leeuwis and Van den Ban, 2004, Marra et al., 2003, Pattanayak et al., 2003, Philp et al., 2019). However, we also know that technologies can be adopted in less prescribed terms, notably in terms of partial adoption, dis-adoption and re-adoption (Alexander et al., 2019, Brown et al., 2017, CIMMYT Economics Program, 1993, Cramb et al., 2015, Feder et al., 1985, Iwueke, 1990, Jain et al., 2009, Jones, 2005, Marra et al., 2003, Moser and Barrett, 2002, Ndagi et al., 2016, Neill and Lee, 2001, Rogers, 2003, Sanders et al., 1996, Tegengne, 2017).

Feder et al. (1985) described the key explanatory factors affecting adoption in a range of studies as: farm size, risk and uncertainty, human capital, labour availability, credit, constraints, tenure, supply constraints and aggregate adoption over time. Pattanayak et al. (2003) found that the factors more likely to be correlated with adoption decisions included: soil quality, extension and training, tenure, savings and credit and assets. Roberts (2015) claimed farmers' production decisions were influenced by mountainous geography, the physical environment, access to infrastructure (water, roads, electricity, irrigation etc.) and markets for their produce. Jones (2005) included farmer perceptions as another important category and found that adoption decisions were influenced by several variables: education, extension, membership, health, cash cropping and soil quality.

Farmers' perceptions of the relative advantage of taking up a new technology or practice are important to adoption outcomes. For example, Pannell et.al. (2006) claim that farmers may consider: (1) short term input costs, (2) yields, (3) prices, (4) medium to long term profits, (5) impacts on other parts of the system, (6) adjustment costs, (7) impacts on the riskiness of production, (8) system compatibility, (9) complexity, (10) government policies, (11) replacement activity costs, (12) existing beliefs and values, (13) family lifestyle, (14) self-image and brand loyalty, (15) environmental credibility and (16) time scale. Refer to Alexander et al. (2019) for more details on factors implicated in technology adoption.

\subsection{Research efforts to understand technology uptake in Lao PDR}

The transition from subsistence to commercial agricultural production in Lao PDR poses serious challenges. Alexander et al. (2018) found that regardless of Lao government rice production forecasts, farmers required specialized and tailored support for their envisaged livelihood and production goals, to allow sectoral transformation. Larson and Alexander (2016) found that households producing surplus rice for sale were not 'market-oriented' rice producers; rather, rice production was viewed as a 
platform on which to construct a diversified livelihood strategy. The key element of the strategy was the most efficient use of family labour, within or beyond the farm. Hence, farmers' production is not driven by government policies and targets, nor technologies that fail to meet their individual production goals. Hence, stakeholders associated with the introduction of technology require a greater understanding of the potential technology users and their preferred behaviours in order to better support technology uptake.

Agricultural research in Lao PDR conducted by Alexander et al. (2019) identified the factors influencing the adoption of innovative technologies by smallholder farmers. Alexander et al. (2019) found that several key attributes of the farmer were important to production decisions and their production goals were heavily dependent on the opportunities or constraints of their local 'agricultural research value chain'. For example, the factors found to influence farmers' propensity to adopt technologies included:(1) being proactive, (2) in need of support, (3) focus on production outcomes, (4) ease of selling produce, (5) trying to generate off-farm income, (6) competitive milling market (rice), (7) labour constraints, (8) risk avoidance and (9) access to storage and transport. The sustained usefulness of the technology was also relevant. Alexander et al. (2019) concluded that research activities should be geared towards farmers who are proactive and responsive to incentives as these farmers are also more likely to persist with the technology and to report benefits.

Moglia et al. (2018) developed a Bayesian Network model describing factors impacting on the chances of Lao smallholder farmers adopting a proposed change to farming practice. They found that a farmer's ability to change production was highly dependent on the farmer's individual views and the technology in question (Moglia et al., 2016). The model provided an opportunity to engage experts and other stakeholders in discussions about their assessment of the technology adoption process, and the opportunities, barriers and constraints faced by smallholder farmers when considering whether to adopt a technology (Moglia et al., 2018). This process provided a situation to co-construct knowledge amongst stakeholders and to tailor support as required by the farmers seeking to diversify production, often only about $25 \%$ of farmers (Alexander et al., 2019).

To assist Lao farmers in commercial agricultural production, Alexander et al. (2017) suggested a blend of pluralistic services, technical and financial assistance, the formation of functioning farmer associations/organizations, and linkages to local, national or international market opportunities, is 
required. A comprehensive set of services - improved extension services, private services, NGOs, and supply chain linkages provided by a variety of actors - is thought to have the best chance of successfully supporting smallholder farmers transitioning into commercial farming. Financial support, favourable agricultural policies, capacity development and development of functional farmer organizations are also essential to support farmers. Alexander et al. (2017) maintained that access to market opportunities continues to be a key motivation with farmers' showing a greater and more sustained interest in innovation when increased production assures financial returns for farmers. Consequently, farmers can be supported to achieve their production goals with agricultural systems support in place, based on their situational requirements and livelihood aspirations.

Fullbrook (2011) reviewed commercial farming production in Lao PDR, where farmers, investors and agricultural officers continued to experience success and failure in their interactions and quest for viable, profitable enterprise agreements. Fullbrook (2011) suggested the need for enduring and trusted relationships between farmers and public/private partnerships to ensure successful production agreements. A key component was to make accurate market information available to farmers.

Technology uptake can often be triggered by changing circumstance. Clarke et al. (2018) reviewed the drivers, barriers and key elements affecting adoption of dry direct seeding methods in southern Lao PDR. They revealed a "perfect storm" of challenges and opportunities that triggered rapid adoption of dry direct seeding technology, although the method had been previously introduced over many years, through multi-organizational efforts and in a number of key rice growing regions (Laing et al., 2015, Clarke et al., 2016, Newby et al., 2013). Clarke et al. (2018) suggested that the unique local microscale complexity of agricultural systems requires a variety of tailored inputs that are more effective than generic support regimes. Changes to agricultural practices take time and require persistence.

\section{Transdisciplinary processes}

We undertook an overall transdisciplinary approach to determine the key influences on technology adoption and to engage stakeholder networks to assist farmers to apply introduced technologies. The overall process is depicted in Figure 1.The genesis of the research project was recognition by both the Lao institutions and funding body that results from a number of projects in southern Lao provinces did not meet expectations. Initially, the proposal development was based on a scoping exercise with Lao 
colleagues. A number of research activities were developed to thoroughly investigate adoption issues. Lao colleagues contributed to development of several research methods, such as: Q methods, Bayesian modelling and gaming theory. They also contributed to instrument designs, clarifying the appropriateness of concepts for Lao culture and language. Joint efforts determined village selection, data collection and discussion on the application of the Research Discussion Tool (RDT). Research activities were co-constructed and administered by international researchers and Lao agricultural researchers from the National Agricultural and Forestry Institute (NAFRI), the National University of Laos (NUoL) and the Department of Technical Extension and Agro-Processing (DTEAP). In the provinces, Provincial Agriculture and Forestry Officers (PAFO), District Agriculture and Forestry Officers (DAFO) and students from NUoL collaborated in data gathering exercises. Research activities involved farmers, heads of villages, government officers, district governors and rice millers, representing key stakeholders of the agricultural research value chain for local rice production.

The design and implementation of the Solution Space Workshop was jointly convened, except where expert facilitation was required to synthesize the comprehensive solution depicted by nine thematic areas (section 4.6). 


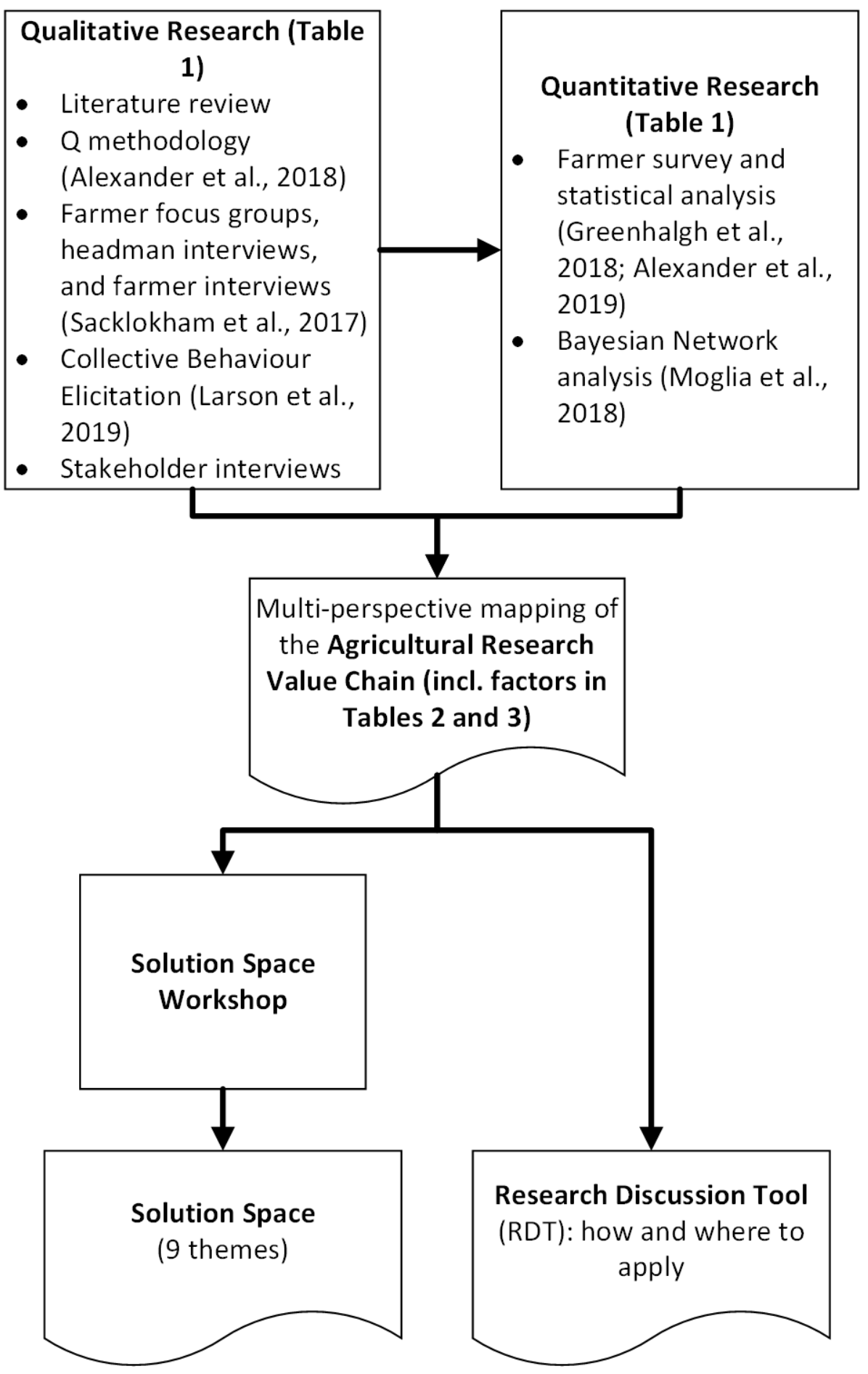

Figure 1: Activities to develop and evaluate the transdisciplinary process

\subsection{Research activities}

We selected several scientific methods to enable triangulation of results using a broad brush research approach. This is essential in a foreign setting, where Australian researchers are not necessarily aware of the normative values, behaviours and beliefs held by smallholder Lao farmers living in 
remote rural areas. A review of the literature on economic impacts and outcomes of agricultural projects operating in southern Lao PDR over the last decade highlighted the socio-economic issues faced by smallholder farmers and the situational elements faced by research teams when introducing new technologies (Larson and Alexander, 2016). We then conducted research activities in selected villages in southern Lao PDR including: focus group discussions, interviews, and surveys, electronic voting, Q methodology, Bayesian Network analysis and agent-based modelling activities. Table 1 indicates the numbers of participants for each research activity. For more details see (Alexander et al., 2019, Alexander et.al., 2018, Alexander et.al., 2016, Alexander and Larson 2016, Larson and Alexander, 2016, Larson et. al., 2019, Moglia et al., 2018, Sacklokham et. al., 2017). Female farmers were encouraged to participate and represented one third of the sample. Findings from individual research activities emphasized constraints, barriers and opportunities that new technologies may present to farmers from a range of viewpoints.

Table 1 Research data collection details from $\mathbf{4 0}$ villages

\begin{tabular}{|c|c|c|}
\hline Research activity & Respondents & Research aim \\
\hline $\begin{array}{l}\text { Village Head } \\
\text { interviews }\end{array}$ & 40 interviews & $\begin{array}{l}\text { Semi-structure interviews } \\
\text { Provided qualitative data outlining key } \\
\text { issues in each village. }\end{array}$ \\
\hline $\begin{array}{l}\text { Adoption factors } \\
\text { ranking }\end{array}$ & $\begin{array}{l}83 \text { rankings ( } 45 \text { male/38 female): } \\
\text { including farmers, PAFO/DAFO, } \\
\text { researchers, students \& } \\
\text { international scientists }\end{array}$ & $\begin{array}{l}33 \text { questions ranked } 0-10 \text { in } \\
\text { importance } \\
\text { Quantitative data on stakeholders' } \\
\text { perceptions of adoption issues. } \\
\text { Informed BN \& CBE activities }\end{array}$ \\
\hline Farmer focus groups & 20 male/20 female groups & $\begin{array}{l}\sim 6 \text { participants/group using a } \\
\text { structured questionnaire } \\
\text { Provided qualitative data for key } \\
\text { gender issues, RDT \& themes }\end{array}$ \\
\hline $\begin{array}{l}\text { Farmer survey and } \\
\text { interviews }\end{array}$ & $\begin{array}{l}114 \text { survey } \& \text { interviews (66 } \\
\text { male/48 female) }\end{array}$ & $\begin{array}{l}\text { Open-ended questions } 5-6 \text { per village- } \\
\text { Preferably participants involved in } \\
\text { previous projects. } \\
\text { Qualitative and quantitative data for } \\
\text { key gender issues, RDT \& themes. } \\
\text { Provided explanatory qualitative } \\
\text { material and village specific production } \\
\text { details. } \\
\text { Informed BN \& CBE activities }\end{array}$ \\
\hline Q methodology & $\begin{array}{l}\sim 2 \text { participants per village } \\
\text { provided } 35 \text { farmers ( } 19 \text { male/16 } \\
\text { female) }\end{array}$ & $\begin{array}{l}\text { Used photographs in a ranking } \\
\text { exercise to elicit qualitative data for } \\
\text { RDT \& themes and key gender issues. } \\
\text { Informed BN \& CBE activities }\end{array}$ \\
\hline $\begin{array}{l}\text { Farmer perception } \\
\text { survey }\end{array}$ & $\begin{array}{l}745 \text { e-voting ( } 452 \text { male/293 } \\
\text { female) }\end{array}$ & $\begin{array}{l}\text { Provided quantitative data } \\
\text { Informed BN \& CBE activities. }\end{array}$ \\
\hline $\begin{array}{l}\text { Stakeholder } \\
\text { interviews: }\end{array}$ & $\begin{array}{l}19 \text { interviews included: District } \\
\text { Directors, District administrators, } \\
\text { District extension staff, rice } \\
\text { millers\& a Lao research scientist }\end{array}$ & $\begin{array}{l}\text { Semi-structured interviews of } \\
\text { stakeholders to understand boundary } \\
\text { issues and supply chain. } \\
\text { Informed BN \& CBE activities. }\end{array}$ \\
\hline $\begin{array}{l}\text { Bayesian Network } \\
\text { (BN) model }\end{array}$ & $\begin{array}{l}\text { The preliminary model was tested } \\
\text { in a provincial workshop with local }\end{array}$ & $\begin{array}{l}\text { Synthesized village and local } \\
\text { stakeholder information into one }\end{array}$ \\
\hline
\end{tabular}




\begin{tabular}{|l|l|l|}
\hline & $\begin{array}{l}\text { experts and stakeholders before } \\
\text { finalizing the BN model. }\end{array}$ & $\begin{array}{l}\text { consistent framework of probabilistic } \\
\text { logic. The BN model answered the } \\
\text { initial research question. "What } \\
\text { influences smallholder adoption of } \\
\text { proven technologies?" }\end{array}$ \\
\hline $\begin{array}{l}\text { Collective Behaviour } \\
\text { Elicitation (CBE) } \\
\text { activities }\end{array}$ & $\begin{array}{l}\text { 4 villages in one district, groups } \\
\text { of 10 participants: 40 men/ 39 } \\
\text { women \& players representing } \\
\text { traders and extension workers }\end{array}$ & $\begin{array}{l}\text { Uncovered tacit and explicit beliefs, } \\
\text { decisions, and actions that lead to } \\
\text { "pinch points" where farmers must } \\
\text { make "go/no-go" decisions regarding } \\
\text { uptake of new technologies. }\end{array}$ \\
\hline $\begin{array}{l}\text { Socio-economic } \\
\text { literature review }\end{array}$ & $\begin{array}{l}\text { Economic impacts and outcomes of agricultural projects operating in } \\
\text { southern Lao PDR. Informed development of surveys, focus group } \\
\text { questions, interview questions and used to develop Bayesian Network (BN) } \\
\text { model and underpinned CBE activities }\end{array}$ \\
\hline
\end{tabular}

Data collection provided an opportunity to conduct transdisciplinary research, where multi-disciplinary knowledge, crossing disciplinary boundaries, was created in a multi-institutional setting. The challenge was to create an holistic approach from the findings of individual research activities, to develop solutions through stakeholder involvement and to ensure outcomes of socially responsible science whereby technology uptake would improve farmers' livelihoods and fit their production goals (Bernstein, 2015). In this way the normative values, behaviours and beliefs held by smallholder Lao farmers became more explicit and collaborative knowledge development/ transfer was enabled.

\subsection{Data synthesis}

Data analysis was conducted on individual research activities to determine the key influences on technology adoption. Triangulation and synthesis of cross-disciplinary data was the initial activity. The volume of data ensured appropriate statistical analysis could be undertaken and qualitative information provided explanatory detail. The key finding was that there was no simple 'solution' that would immediately improve rates of adoption. Rather there was a complex ecology of factors that contribute to a spectrum of adoption decisions. Figure 2 outlines the conceptual framework that was derived from our research. Examples of the factors within the conceptual diagram (Fig 2.) are presented in Table 2 while an example of the key factors that influence the introduction of a specific technology, direct seeding application for rice production, are presented below Figure 3 . 


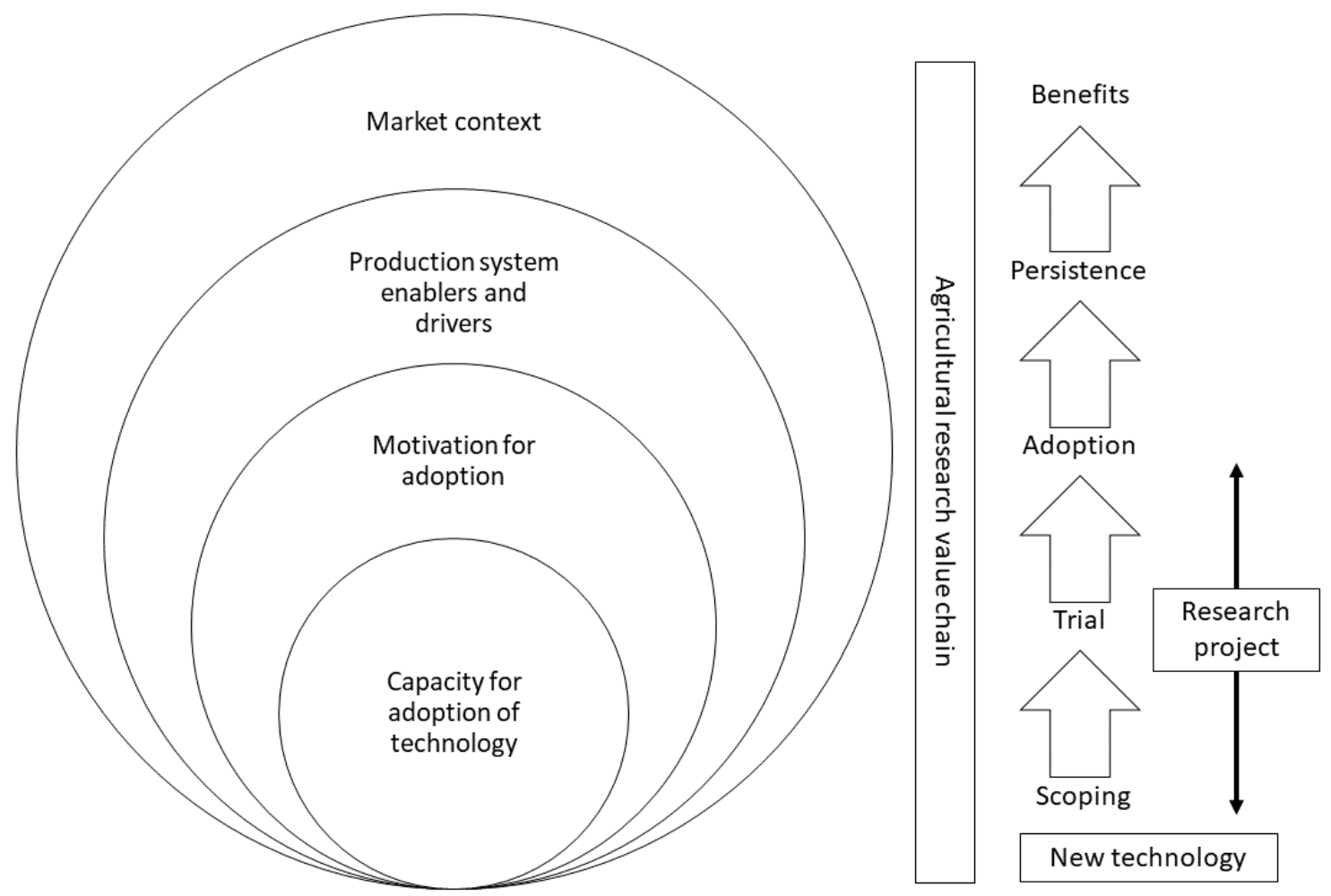

Figure 2 Conceptual diagram of influences on farmers' decisions

Note that farmers continually evaluate the usefulness of technology and suitability for their production system and while they do adopt technologies, dis-adoption and/or partial adoption can occur over time.

Table 2 indicates the initial set of factors derived from research activities. These factors were examined by a broad group of stakeholders in a workshop setting with several additional factors included by splitting some factors into respective components. The final selection is available in Annex A. 


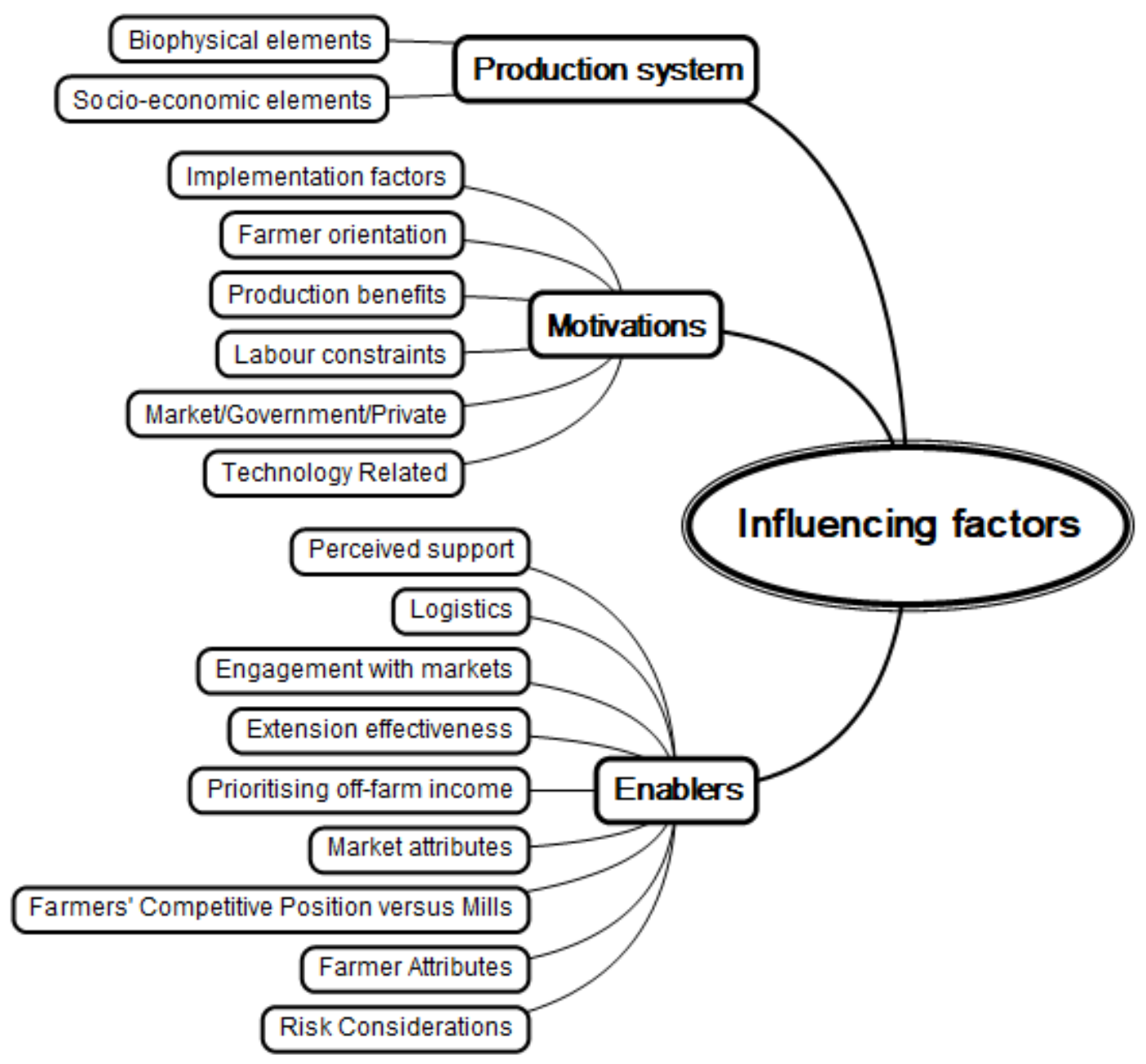

Figure 3 The initial set of factors within the farmers' production system, farmers' decision drivers/motivators and farmers' decision enablers that influence technology uptake.

Under the hierarchy of factors described in Figure 3, the following provides an example of 32 RDT factors for direct seeding technology. The subset could be further tested through facilitated workshop activities to determine the quintessential components important to the introduction and uptake of direct seeding technology:

- Biophysical elements: Suitable land, Soil, Water, Rice varieties/availability, Plant/livestock, disease, Pesticide, Vaccination, Fencing, Fertilizer, Weeds. 
- Socio-economic elements: Farmer mindset, Production/social calendar, Cost of technology, Price of labour, Farmers' technical capacity, New technology - required training, inputs etc., Land ownership, PAFO/DAFO extension activities.

- Research Project Implementation: Solves main problem; Guiding coalition ready (e.g. village support); Outcomes understood; Help available if needed (e.g. village/external); Trialable - the technology can be trialed prior to commitment.

- Farmers' Orientations: Size of benefit (profit); Quick wins (seasonal); Labour requirements; Time/labour availability; How different to what I do now?; Adoption behavior (when/what/how long); Trust (in the technology); Attitude to risk of failure; Level of trust in perceived benefit.

- Production Benefits: Reduced input costs (e.g. reduced labour); Crop productivity; Ease/convenience.

- Community Attributes: Traditions; Social influence; What does my neighbour do?

- Labour Constraints: Perceived cost of change (e.g. additional labour).

- Market/Government/Private: Market access; Fit with government policy; Public/private support.

- Technology Related: Access to new technology, Affordability of new technology, Reputation of technology, Interest in new technology.

- Perceived Support: Technical support; First adopters; Clear expectations.

- Engagement with Markets: Improving livestock; Multiple rice buyers; Fair prices for rice.

- Extension Effectiveness: Interaction with DAFOS; Skills; Regular visits to the village by DAFOS.

- Logistics: On-farm/local storage, Multiple transport providers.

- Market Attributes: Easy to sell, Commodity prices (down or up), Global rice competition (access to markets), Traders (number and relationships), Farmer groups (effectiveness), Trader/farmer agreements.

- Farmers' Competitive Position versus Mills: Multiple mills, Local market prices for rice.

- Farmer Attributes: Trust, Labour, Fairness, Farmer co-operation, Skills/knowledge, Complex technology - training required, Impact on the seasonal calendar, Maintenance/repair of machinery.

- Risk Considerations: Size of risk-small? 
It was noted that the relative importance of each factor in the above list is dependent on the specific technology being introduced and the local context for the farmer. The large number of interacting factors implicated in technology uptake explains in part why many technical projects do not achieve their expected rates of adoption. An important conclusion is that there are numerous factors that need to be addressed for a given technology to be adopted on a broad scale. Researchers are not normally in a position to address all these factors and initially, projects may not be in a position to recognize more than a few important drivers/motivators and enablers. We argue that boosting adoption is a highly complex issue.

\subsection{Creating a 'Solution Space'}

A 'Solution Space' is a process based on change management models and tools shown to influence the practice of change leadership and assist in planned change for complex organizations (Beckhard and Harris, 1987). These tools and methods allow multiple perspectives to be heard, enabling a diverse number of opinions to be aired and sensitive or mutually exclusive views to be discussed by group members. This serves to remove blindspots, and critically evaluate assumptions on which the success of technology relies. In this 'Solution Space', discussions were supported by our concurrent situational, contextual research findings, covering all the key factors that have been identified through our research. All workshop material and discussions were conducted primarily in Lao language and occasionally through interpreters; with all presentations in Lao script. Hence, a significant two-way transfer of knowledge was achieved. Importantly, this approach allowed junior through to senior staff to contribute in meaningful ways to discussions. This was important as many provincial and district staff attended the workshop and had an opportunity to share their local knowledge. Facilitation methods enabled a trusting environment to be established; one within which the voices of junior staff and the relatively powerless (lower ranked staff, female staff etc.) to be heard whilst also allowing authority figures to finalize decisions. A crucial consideration is the hierarchical nature of the governance systems and leadership within Lao PDR (Case et al., 2017). The outcome 'Solutions' are a combination of strategic/institutional, economic/social/political and operational/local actions to be formulated and implemented within various timeframes. Importantly, this approach generates a high level of ownership of 'solution/s' by those who will have to implement change.

\section{4 'Solution Space' workshop}


We held a workshop to collaboratively reflect on the key influences on technology adoption and to determine how to engage stakeholder networks to assist farmers to apply introduced technologies. The Solution Space workshop held in December 2016 was designed to review key research results and formulate a comprehensive solution to enhance technology adoption in rice-based agricultural systems in southern Lao PDR. The workshop was designed around the principles and practices of change management (Beckhard and Harris, 1987, Greenhalgh and Alexander, 2017). During the 3day workshop all possible 'solutions' or parts of 'solutions' that could be implemented to address the main areas of concern that arose from the factor synthesis (Tab.2) were discussed. Initially, the conceptual diagrams (Fig.2 and Fig. 3) were presented to Lao colleagues and provincial stakeholders and during the workshop a comprehensive set of decision drivers/motivators and decision enablers for a 'generalized technology' were formulated and termed the Research Discussion Tool (RDT). Details are available in the report by Greenhalgh and Alexander (2017). In addition, a set of 9 areas representing a higher abstraction of the synthesis was achieved in break-out group activities, confirmed by consensus workshop activities. The workshop outcome designated the 'Solution Space' was formulated and is represented by the RDT and the 9 themed areas. The broad nature of the 9 solution areas and 78 factors within the RDT tool suggests that the 'Solution Space' is comprehensive and can be adapted for use with other technologies, regions and countries with relatively minor modification. Figure 3 depicts the process used to develop and evaluate the RDT.

\subsection{Constructing the Research Discussion Tool}

Results were synthesized into discussion guidelines for researchers/technical officers in the form of a Research Discussion Tool - incorporating 78 factors with a traffic light action system for use by project personnel and local government officials to elicit local knowledge Annex A. The co-constructed RDT (adoption drivers/motivators, enablers, opportunities, barriers etc.), was envisaged as a platform for discussions between stakeholders to gain a common understanding of the technology and then to select suitable villages to introduce a specific technology. Subsequently, the efficacy of the RDT was established through collaboration with several concurrent agricultural technology projects (Greenhalgh et al., 2018). Immediate uses of the RDT were deduced by team members for: (a) selection of villages; (b) review of previously selected villages; and (c) guidelines for monitoring and evaluation (M\&E) activities. In addition, it was envisaged that the tool would be useful in the project proposal stage to identify the significant factors for the project-specific technology. The tool would also be suitable as an 
adapted planning and management tool. Finally, it was foreseen that the tool could identify lessons learnt at the close of the project.

Note that the RDT is designed to prompt discussions between researchers, government staff, men, women and young farmers and people involved in the supply chain. The tool is to be used when a new technology is introduced. The tool is constructed for a specific technology by the project teams through discussions of what is important from the list of 78 factors for that technology (Annex A). While gender issues, the role and implications for women when using an introduced technology are not explicit, the discussions prompted by the RDT guide (Annex A) allows for voices, opinions and implications to be aired.

\subsection{Thematic areas influencing technology uptake}

A second outcome of the Solution Space Workshop was the articulation of 9 thematic areas. These 9 'focus' areas all have the potential to have an influence on the adoption of new technologies. These areas are abstracted factors arising from the RDT, the implications of these factors and additional areas that impact adoption. The 9 thematic areas were developed through extensive deliberation within the workshop process and were finalized to include: (1) Proposal process, (2) Markets, (3) Private sector, (4) Extension effectiveness, (5) Training, (6) Farmer organizations, (7) Policy support, (8) Institutional organization and (9) Monitoring and evaluation.

Three areas that impact technology adoption and do not directly affect farmers were included in the thematic areas: (1) Proposal process, (7) Policy support (government) and (8) Institutional organization (intercollegiate practices). In order to operationalize the 9 thematic areas, Lao partner organizations were asked to select an area of concern in which they would undertake research activities. Nominally, these 'Project Charters' were established to outline research activities that our Lao partners from 3 national institutions would address in order for our overall project to have an impact at the high thematic level and to further assess adoption potentials.

Our partnership model required Lao colleagues to decide their priorities in addressing the 9 areas including:

1) Proposal development process: The research proposal is an essential starting point for improving farmer adoption rates of new technologies. Many of the issues that arise in the field 
could be eliminated or heavily mitigated through a gentle modification of the proposal development process. For example, a well-planned and extended scoping exercise designed to answer all the relevant questions about the research project (using the RDT and 9 themes), would tend to eliminate most of the common issues arising in research for development projects. This could also be achieved by including an "adoption expert" in the research team who has considerable influence over the research design.

2) Markets: The relevant details concern the availability and accessibility of markets, as well as pricing of any additional output or products resulting from the adoption of new technologies.

3) Private sector actors: This area concerns the mobilization of private sector partners that can have a direct impact on farmer adoption issues. For practical purposes, this area may have to be combined with 'markets' above, for a more comprehensive solution. It was noted that in Lao PDR the term 'private sector organization' refers to all actors in the end-to-end supply chain. The terms supply chain and value chains are often used interchangeably.

4) Extension effectiveness: The effectiveness of the extension role is a crucial determinant in lifting farmer adoption rates of new technology. Precisely how this role is carried out and how to overcome current constraints (e.g. skill/knowledge gaps) are issues to be addressed.

5) Training: Training is recognized as a key enabler to lift adoption rates. Specifically, Lao colleagues involved in extension activities require training across a number of areas including technical aspects of agriculture relevant to Lao conditions: technical aspects of specific technologies being introduced, management and organization skills, and people-oriented skills to improve adoption rates such as presentation skills, technology demonstration skills and facilitation skills.

6) Farmer organizations: Farmer cooperation is seen as an effective vehicle to aid in boosting adoption rates of new technology. The exact nature, role and operating method of farmer organizations are current topics of discussion.

7) Policy support: Current Government of Lao policy is to raise farmer incomes. This area provides an opportunity to review current policy initiatives with a view to identifying further policy options that could facilitate farmer adoption rates.

8) Institutional organization: There is a view that a permanent 'taskforce' consisting of key staff from local academic institutions and relevant government organizations (NAFRI, NUOL and 
DAEC) may improve the effectiveness of managing, in particular, large complex research projects.

9) Monitoring and evaluation (M\&E): To enable ongoing learning and improvement, this area looks at the effectiveness of current M\&E in ensuring that the potential benefits of new technology are actually realized, and also that management frameworks achieve expected results.

When deciding their priorities, choices in the deployment and activation of meaningful ground level actions across the 9 areas were guided by the degree of difficulty and institutional capacity. For example, the area involving (5) Training - particularly of extension officers (i.e. PAFOS/DAFOS in the Lao context) appeared relatively straightforward, albeit expensive. Actions in the areas of Markets (2) and Private Sector (3) were inherently difficult due to local factors.

The final day of the 3-day Solution Space workshop involved senior Lao officials who were presented with workshop developments explaining the key influences of smallholder technology adoption and the 'solutions' that would improve adoption rates formulated through the RDT and 9 thematic areas. A key item in the discussion was recognition of the need to connect with the farmer. The effective use of the Solution Space as represented by the RDT and the 9 themes has been designed to do exactly that. Senior Lao officials had an opportunity to discuss workshop outcomes with national, provincial and district staff within the Ministry of Agriculture and Forestry.

\section{Discussion}

Scoones (2009) developed the sustainable livelihoods framework as a checklist of issues that impact rural development used to guide contextual understanding and discussions of key issues. Using change management techniques to mobilize scientific research findings, we present a participatory and more targeted approach to understanding the core elements (factors) that influence rural transitions toward agricultural commercialization through the introduction of new technologies. We have illustrated a process that creates new hybrid knowledge systems involving actors with different worldviews, positions and knowledges. We have described a deliberative process used to inform research priorities, problem definitions and research options as suggested by (Vogel et al., 2007). Bernstein (2015) and Scoones et al. (2018) agree that co-constructed new knowledges are essential for transdisciplinary research, to form creative solutions by involving stakeholders and ensuring 
socially responsible science results. In this paper, we have outlined a process that reflects on realworld problems and combines expert facilitation to enable co-designed research that correctly applied, engages stakeholders and lifts the probability of impact (Blythe et al., 2017, Davila et al., 2018, van Kerkhoff and Lebel, 2015). By co-constructing new knowledge and engaging stakeholders, our approach provides a participatory method for arriving at solutions for the particular issue of creating value from agricultural technology for smallholder farmers (Jasanoff, 2004).

\subsection{Principles of co-constructed knowledge}

Based on the outcomes of the workshop we are able to deduce a series of principles that might usefully inform the co-construction of knowledge in the context of rural development. Our recommendations are that: (1) all project participants and other stakeholders to be involved in implementation activities have an opportunity to contribute to 'solution space' discussions; (2) a broad range of participants is important for quality informed discussions to take place; (3) all ideas are accepted and considered in activities that lead up to articulating the 'solution space' (4) some ideas may be discarded later during the evaluation/testing phase; (5) ideas may be contributed by individuals or groups and in the workshop process ideas are converted into one or more of the integrative solutions; (6) the solution(s) is then tested and evaluated for completeness; and (7) preimplementation planning and detailed implementation plans are subsequently developed and enacted. Furthermore, for successful transdisciplinary processes to be conducted attention is required to ensure a broad group of relevant stakeholders participate, that power imbalances or biases from different disciplines/knowledge types or perceived stakeholder positions are mitigated, that gender aspects are fully considered and sensitive issues and differences in perspectives are managed.

\subsection{Efficacy of the solution(s)}

International development cooperation programs struggle to achieve sustainable results by failing to respond to the dynamics of local stakeholders' relations (Khaled, 2018). Ratner et al. (2018) claim that multi-stakeholder dialogue, understanding context-specific local issues and research project flexibility are all essential to project success. By adapting change management techniques, we have shown that new knowledge can be created and used to design effective solutions to the barriers, constraints and opportunities that farmers face in relation to technology adoption. This approach also has the potential to harness collaborative exchanges with other projects that are often using the same Lao government staff while introducing different technologies in similar geographical regions. 


\subsection{Limitations of the study}

Some important limitations of our research are listed here:

- The original research was undertaken, for good reasons, in a way that was not technology specific. Accordingly, our analysis identifies an array of factors that can influence technology adoption. However, we believe that more targeted and innovation-specific use of the RDT and 9 areas would pinpoint more precisely the factors that are most germane for any given technology. Further research is required to explore technology- and product-specific issues in light of the agricultural research value chain pertinent to a specific technology (see Alexander et al., 2019).

- To ensure that the tool works as expected, further formal evaluation of the effectiveness of the RDT is required and hence is a current limitation. Further research is required in order to adequately evaluate the cost, benefits and value proposition of using the tool, developing solutions and accounting for contextual thematic influences.

- This research has largely been undertaken with the assumption that technology adoption is positive both for farmers and for the community in general, but this is clearly not always the case, and before embarking on activities to boost adoption rates, careful consideration must be given to properly understand the often unpredictable outcomes of technology adoption.

\section{Evaluation}

The RDT has been successfully trialled in concurrent research projects for specific technologies such as dry season cropping, forage production, use of greenhouses and a 'best practice' project (Greenhalgh et al., 2018, National University of Laos (NUoL), 2018). The use of the RDT in projects at various stages of project progression has enabled discussions between diverse stakeholders. Discussions highlighted the barriers and constraints to adoption when introducing technologies, which tended to vary according to the technology, project and/or region. The RDT created a platform for important discussions for stakeholders to gain a common understanding of the technology and the requirements for productive adaption. Use of this process should theoretically increase adoption rates through better village selection processes and allow for stakeholders to more fully understand the technology and requirements for productive technology adoption. 
Recommendations from the initial trialling of the RDT indicated that the tool was useful and ensured collaborative activities were purposeful and successful. The selection of participants was critical to the success of establishing the most important factors for a given technology. Involving farmers in these discussions verified the accuracy and efficacy of the tool (National University of Laos (NUoL), 2018).

Several project teams have been surprised that their project trials have not been fully understood by government staff and farmers and that future significant efforts are required to ameliorate these difficulties prior to the project successfully progressing. For example, the cost of a recommended greenhouse was six times greater than available Chinese greenhouses, and hence unlikely to be adopted as ripened fruit do not gain a higher price at market. A best-practice project was unable to articulate best practices and hence there was an inability to communicate project details to Lao researchers and farmers. If these details continue to be overlooked, adoption uptake will continue to be less than anticipated. Lao researchers have been empowered to question the veracity of the introduced techniques and the complex nature of adoption- thereby deflecting blame for failed adoption outcomes.

Research activities are planned to evaluate the impact of the use of the RDT in scoping exercises to support the design phase of newly proposed projects, subject to directives by the funding body. A more detailed evaluation of the tool will be provided in forthcoming publications.

\section{Conclusion}

The Lao government's agricultural strategies and policies aim to support greater agricultural productivity in key geographic regions, particularly in the more fertile plains in Southern Lao PDR, by supporting a gradual transition from subsistence to commercial smallholder production. In this paper we have reported on an integrative and deliberative research process of engagement with multiple stakeholders (farmers, private sector actors, government agencies and researchers) used to determine the supporting conditions required to maximize the likelihood of farmers' technology uptake. The process involved assisting Lao national researchers and extension agents to co-develop solutions in line with government policies to increase productivity in targeted areas of southern Lao PDR.

This research has shown that there are usually no simple 'one- or two-factor' solutions to technology uptake; rather we have found a typically more complex ecology of factors - farmers' decision 
motivations and farmers' decision enablers within farmers' production systems. The relative importance of each factor is dependent on the specific technology that is introduced. Hence, projects that introduce new technologies struggle to address all relevant factors and often do not have the ability to deal with the complex array of factors that are at play. A key benefit of the outcomes of this research, the RDT and the 9 thematic areas, identify solutions, factors and areas of concern for a specific technology through co-constructed knowledge that builds capacity and embeds local knowledge within projects.

In this paper we have reported on the application of a transdisciplinary approach and argued that it provides an effective method of investigating the relative potential and value of uptake of agricultural technology by smallholder farmers. Change management practices used in organizational change have been shown to be powerful tools that can generate ownership and leadership within a research program. We have designed an innovative tool to assist stakeholders understand more about the introduced technology and to identify suitable villages, and hence farmers, likely to adopt the new technology. In addition, we have described 9 themes that represent a comprehensive, end-to-end, solution to the adoption of new technologies with the potential to enhance the future probability of adoption of new technology.

\section{Acknowledgements}

Funding: This work was supported by the Australian Centre for International Agricultural Research (ACIAR) [Project no. ASEM/2014/052: 'Smallholder farmer decision-making and technology adoption in southern Lao PDR: opportunities and constraints']. We are grateful to ACIAR for their support. We would also like to thank staff based in our Lao partner institutions for their support and assistance, namely, colleagues at the National University of Laos, the National Agriculture and Forestry Institute and the Department of Technical Extension and Agro-Processing. Fieldwork conducted for the study was approved by James Cook University's Human Ethics Research Committee: Approval H6109. Declarations of interest: none.

\section{References}

Alcon, F., Tapsuwan, S., Martínez-Paz, J. M., Brouwer, R., \& de Miguel, M. D. 2014. Forecasting deficit irrigation adoption using a mixed stakeholder assessment methodology. Technol. Forecast. Soc. Chang., 83, 183-193. 
Alexander, K., Case, P., Jones, M., \& Connell, J. 2017. Commercialising smallholder agricultural production in Lao People's Democratic Republic. Development in Practice, 27, 965-980.

Alexander, K., Greenhalgh, G., Moglia, M., Thephavanh, M., Sinavong, P., Larson, S., Jovanovic, T., \& Case, P. 2019. What is technology adoption? Exploring the agricultural research value chain for smallholder farmers in Lao PDR. Agriculture and Human Values, 15 June 2019, https://doi.org/10.1007/s10460-019-09957-8.

Alexander, K., \& Larson, S. 2016. Smallholder farmer decision-making and technology adoption in southern Lao PDR: opportunities and constraints. Activity 1.5: Stakeholders perceptions. Report for ACIAR ASEM/2014/052 project 'Smallholder farmer decision-making and technology adoption in southern Laos: opportunities and constraints'. Canberra, ACT, Australia: ACIAR. Web site https://sites.google.com/view/acrtechnologyadoption/projectreports

Alexander, K., Larson, S., Case, P., Parry, L., Thammavong, P., Jovanovic, T., Moglia, M., Connell, J., Khounsy, B., \& Sacklokham, S. 2016. Smallholder farmer decision-making and technology adoption in southern Lao PDR: opportunities and constraints. Activity 1.5: Stakeholders perceptions- Adoption Factors and Q Methodology. Report for ACIAR ASEM/2014/052 project 'Smallholder farmer decision-making and technology adoption in southern Laos: opportunities and constraints'. Canberra, ACT, Australia: ACIAR. Web site https://sites.google.com/view/acrtechnologyadoption/project-reports

Alexander, K. S., Miller, J., \& Lipscombe, N. 2010. Sustainable development in the uplands of Lao PDR. Sustainable Development, 18, 62-70.

Alexander, K., Parry, L., Thammavong, P., Sacklokham, S., Pasouvang, S., Connell, J., Jovanovic, T., Moglia, M., Larson, S., \& Case, P. 2018. Rice farming systems in Southern Lao PDR: Interpreting farmers' agricultural production decisions using Q methodology. Agricultural Systems, 160, 1-10.

Ayele, S., Duncan, A., Larbi, A. \& Khanh, T.T. 2012. Enhancing innovation in livestock value chains through networks: Lessons from fodder innovation case studies in developing countries. Science and Public Policy, 39, 333-346. 
Basu, S., \& Leeuwis, C. 2012. Understanding the rapid spread of system of rice intensification (SRI) in Andhra Pradesh: Exploring the building of support networks and media representation. Agricultural Systems, 111, 34-44.

Beckhard, R., \& Harris, R. T. 1987. Organizational transitions: Managing complex change. University of Michigan, Addison-Wesley Publishing Company.

Bernstein, J. H. 2015. Transdisciplinarity: A review of its origins, development, and current issues. Journal of Research Practice, 11(1) Article R1.

Biggs, S. 2007. Building on the positive: an actor innovation approach to finding and promoting propoor institutional and technical innovations. International Journal Agricultural Resources, Governance and Ecology and Society, 6(2) (special issue on institutional change in agricultural innovation systems), 144-164.

Blythe, J., Nash, K., Yates, J., \& Cumming, G. 2017. Feedbacks as a bridging concept for advancing transdisciplinary sustainability research. Current Opinion in Environmental Sustainability, 2627, 114-119.

Brown, P. R., Nuberg, I., \& Llewellyn, R. 2017. Stepwise frameworks for understanding the utilisation of conservation agriculture in Africa. Agricultural Systems, 153, 11-22.

Case, P., Connell, J., \& Jones, M. 2017. The language of leadership in Laos. Leadership, 13(2), 173193.

Cash, D. W. 2000. In order to aid in diffusing useful and practical information: Cross-scale boundary organizations and agricultural extension. Harvard University, Belfer Center for Science and International Affairs, John F. Kennedy School of Government.

Chambers, R. 1983. Rural development: Putting the last first. London, Longman.

CIMMYT Economics Program. 1993. The adoption of agricultural technology: A guide for survey design. Mexico, D.F.: CIMMYT. Web site https://libcatalog.cimmyt.org/Download/cim/42412.pdf .

Clarke, E., Jackson, T., Keoka, K., \& Phimphachanvongsod, V. 2016. Study of farmer experiences and approaches with mechanised dry direct seeding in Savannakhet province: Crop-livestock systems platform for capacity building, testing practices, commercialisation and community learning (CSE/2014/086). ACIAR, Canberra. 
Clarke, E., Jackson, T. M., Keoka, K., Phimphachanvongsod, V., Sengxua, P., Simali, P., \& Wade, L. J. 2018. Insights into adoption of farming practices through multiple lenses: an innovation systems approach. Development in Practice, 28(8), 983-998. DOI:

10.1080/09614524.2018.1504890

Collinson, M. 2000. Part 1: Understanding farmers and their farming. Editorial introduction. In: Collinson, M. \& FAO (eds.) A history of Farming Systems Research. CAB International, Wallingford, Oxon, UK: FAO and CABI Publishing.

Cook, S. 2006. Structural change, growth and poverty reduction in Asia: Pathways to inclusive development. Development Policy Review, 6, s51-80.

Cramb, R. A., Gray, G. D., Gummert, M., Haefele, S. M., Lefroy, R. D. B., Newby, J. C., Stür, W., \&. Warr, P. 2015. Trajectories of rice-based farming systems in mainland Southeast Asia. ACIAR, Canberra: Australian Centre for International Agricultural Research. ACIAR Monograph No. 177.

Davila, F., Dyball, R., \& Amparo, J. M. 2018. Transdisciplinary research for food and nutrition security: Examining research-policy understandings in Southeast Asia. Environmental Development, $28,67-82$

Dias, C. S. L., Rodrigues, R. G., \& Ferreira, J. J. 2019. What's new in the research on agricultural entrepreneurship? Journal of Rural Studies, 65, 99-115.

Douthwaite, B., Apgar, J. M., Schwarz, A.-M., Attwood, S., Sellamuttu, S. S., \& Clayton, T. 2017. A new professionalism for agricultural research for development. International Journal of Agricultural Sustainability, 15(3), 238-252.

Douthwaite, B., \& Hoffecker, E. 2017. Towards a complexity-aware theory of change for participatory research programs working within agricultural innovation systems. Agricultural Systems, 155, 88-102.

Douthwaite, B, Keatinge, J.D.H., \& Park, JR. 2001. Why promising technologies fail: The neglected role of user innovation during adoption. Research Policy, 30(5), 819-36

FAO. 2019. Laos at a glance Web site http://www.fao.org/laos/fao-in-laos/laos-at-a-glance/en/.

Farrington, J., \& Martin, A. 1988. Farmer participation in agricultural research: a review of concepts and practices. Agricultural Administration Unit Occassional Paper 9.: ODI. 
Feder, G., Just, R. E., \& Zllberman, D. 1985. Adoption of agricultural innovations in developing countries: A survey. Economic Development and Cultural Change, 33, 255-298.

Friederichsen, R., Minh, T. T., Neef, A., \& Hoffmann, V. 2013. Adapting the innovation systems approach to agricultural development in Vietnam: challenges to the public extension service. Agric Hum Values, 30, 555-568.

Fullbrook, D. 2011. Smallholder production agreements in the Lao PDR: Qualifying Success. Laos: Laos Extension for Agriculture Project (LEAP) for the Government-Donor Sub Working Group on Farmers and Agribusiness. Vientiane, Swiss Agency for Development and Cooperation.

Gardner, K., \& Lewis, D. 1996. Anthropology, development and the post-modern challenge. London, Pluto Press.

Geels, F. W., \& Schot, J. 2007. Typology of sociotechnical transition pathways. Research Policy, 36, 399-417.

Geels, F. W., \& Schot, J. 2011. A multi-level perspective on transitions. In: Grin, J., Rotmans, J., \& Schot., J. (eds.) Transitions to sustainable development: New directions in the study of long term transformative change (Routledge Studies in Sustainability Transitions) Amsterdam, Netherlands, Routlegde.

German, L., Mowo, J., \& Kingamkono, M. 2006. A methodology for tracking the "fate" of technological interventions in agriculture. Agriculture and Human Values, 23, 353-369.

Ghadim, A. A., \& Pannell, D. J. 1999. A conceptual framework of adoption of an agricultural innovation. Agricultural Economics, 21(2), 145-154.

Gilles, J. L., Thomas, J. L., Valdivia, C., \& Yucra, E. S. 2013. Laggards or leaders: conservers of traditional agricultural knowledge in Bolivia. Rural Sociology, 78, 51-74.

Greenhalgh, G., \& Alexander, K. 2017. Smallholder farmer decision-making and technology adoption in southern Lao PDR: Activity 2.1 Solution Spaces. Canberra, ACT, Australia: ACIAR. Web site https://sites.google.com/view/acrtechnologyadoption/project-reports

Greenhalgh, G., Larson, S., Alexander, K., Thammavong, P., Sacklokham, S., Pasouvang, S., Thaphavanh, M., Khounsy, B., \& Sisphaythong, T. 2018. Development, testing, monitoring and evaluation of the Research Discussion Tool (RDT). Smallholder farmer decision-making and technology adoption in southern Lao PDR: opportunities and constraints. ACIAR. Web site https://sites.google.com/view/acrtechnologyadoption/project-reports 
Griliches, Z. 1957. Hybrid corn: an exploration in the economics of technological change. Econometrica, 25, 501-523

Hailu, B. K., Abrha, B. K., \& Weldegiorgis, K. A. 2014. Adoption and impact of agricultural technologies on farm income: Evidence from Southern Tigray, Northern Ethiopia. International Journal of Food and Agricultural Economics, 2(4), 91-10.

Hall, A., Janssen, W., Pehu, E., \& Rajalahti, R. 2006. Enhancing agricultural innovation: How to go beyond the strengthening of research systems. Agricultrure and Rural Development Washington, DC: The International Bank for Reconstruction and Development/The World Bank.

Hogset, H. 2005. Social networks and technology adoption. American Agricultural Economics Association Annual Meeting, July 24-27, 2005. Providence, Rhode Island.

Iwueke, C. C. 1990. Adoption behaviour of farmers toward yam minisett technique in Imo state Nigeria. Nigerian Agricutural Journal, 25, 16-17.

Jain, R., Arorra A., \& Raju. S. S. 2009. A novel adoption index of selected agricultural technologies: Linkages with infrastructure and productivity. Agricultural Economics Research Review, 22, $109-120$.

Jasanoff, S. 2004. States of knowledge: the co-production of science and social order. London, Routledge.

Jiggins, J. 2000. Forward. In: Collinson, M. (ed.) A history of farming systems research CAB International, Wallingford, Oxon, UK: FAO and CABI Publishing.

Jones, K. M. 2005. Technology adoption in West Africa: adoption and disadoption of soybeans on the Togo-Benin border. Master of Science dissertation, Department of Natural Resource Management. Raleigh, NC :North Carolina State University, USA.

Kebede, Y. 1992. Risk behavior and new agricultural technologies: the case of producers in the central highlands of Ethiopia. Quarterly Journal of International Agriculture, 31, 269-284.

Khaled, K. 2018. Stakeholders' relations and power dynamics in development cooperation: lessons learnt from Egypt. Development in Practice, 28, 785-798.

Klerkx, L., \& Nettle, R. 2013. Achievements and challenges of innovation coproduction support initiatives in the Australian and Dutch dairy sectors: a comparative study. Food Policy, 40, 7489. 
Knowler, D. 2015. Farmer Adoption of Conservation Agriculture: A Review and Update: Springer International Publishing.

Knowler, D., \& Bradshaw, B. 2007. Farmers' adoption of conservation agriculture: A review and synthesis of recent research. Food Policy, 32(1), 25-48.

Laing, A., Roth, C., Gaydon, D., Phengvichith, V., Sipaseuth, Thiravong, K., Vorlasan, S., \& Schiller, J. 2015. Combining field trials and crop modelling of dry direct seeded rice to reduce production risks in Lao PDR under current and future climates.Building Productive, Diverse and Sustainable Landscapes: Proceedings of the 17th ASA Conference, 20-24 September 2015, Hobart, Australia. Web site www.agronomy2015.com.au.

Lamprinopoulou, C., Renwick, A., Klerkx, L., Hermans, F., \& Roep, D. 2014. Application of an integrated systemic framework for analysing agricultural innovation systems and informing innovation policies: Comparing the Dutch and Scottish agrifood sectors. Agricultural Systems, 129, 40-54.

Leeuwis, C., \& A. Van den Ban, A. 2004. Communication for rural innovation: Rethinking agricultural extension. Oxford: Blackwell Science.

Larson, S., Perez, P., Giger-Dray, A., Moglia, M., Thammavong, P., Thephavanh, M., Sodahak, V,. Khounsy, B., Philp, J., Boyd, D., \& Alexander, K. 2019. What influences smallholder adoption of proven agricultural technologies? Identifying differences in men and womens' agricultural production decision making in southern Laos using Collective Behaviour Elicitation (CBE) Gaming activities. Seeds of Change Conference, Canberra University, 2nd-4th April 2019.

Larson, S., \& Alexander, K. 2016. Smallholder farmer decision-making and technology adoption in southern Lao PDR: opportunities and constraints. Activity 1.4 Summary of the secondary livelihoods and economic data. Report for ACIAR ASEM/2014/052 project 'Smallholder farmer decision-making and technology adoption in southern Laos: opportunities and constraints'. Canberra, ACT, Australia: ACIAR. Web site https://sites.google.com/view/acrtechnologyadoption/project-reports

Latour, B. 1998. From the world of science to the world of research? Science and Engineering Ethics, 280, 208-209.

Ministry of Agriculture and Forestry (MAF). 2010. Strategy for Agriculture Development 2011 to 2020: Sector Framework, Vision, and Goals Agriculture and Forestry for Sustainable Development, 
Food and Income Security. Retrieved from

http://theredddesk.org/sites/default/files/strategy_for_agricultural_development_2011_to_2020 _1.pdf

Manivong, V., Cramb, R., \& Newby, J. 2014. Rice and remittances: Crop intensification versus labour migration in southern Laos. Human Ecology, 42, 367-379.

Marra, M., Pannell D. J., \& Ghadim. A. A. 2003. The economics of risk, uncertainty and learning in the adoption of new agricultural technologies: where are we on the learning curve? Agricultural Systems, 75, 215-234.

Ministry of Planning and Investment 2016. The 8th Five-Year National Socio-economic Development Plan (2016-2020) .Officially approved at the VIIIth National Assembly's Inaugural Session, 20-23 April 2016, Vientiane.

Moglia, M., Alexander, K., \& Connell, J. 2016. Developing a Bayesian Network model to describe technology adoption by rice farmers in Southern Laos. Report for ACIAR ASEM/2014/052 project 'Smallholder farmer decision-making and technology adoption in southern Laos: opportunities and constraints'. Melbourne: CSIRO. Web site https://sites.google.com/view/acrtechnologyadoption/project-reports

Moglia, M., Alexander, K., Thephavanh, M., Thammavong, P., Sodahak, V., Khounsy, B., Vorlasan, S., Larson, S., Connell, J., \& Case, P. 2018. A Bayesian Network model to explore practice change by smallholder rice farmers in Lao PDR. Agricultural Systems, 164, 84-94.

Morris, W., Henly, A., \& Dowell, D. 2017. Farm diversification, entrepreneurship and technology adoption: Analysis of upland farmers in Wales. Journal of Rural Studies, 53, 132-143.

Moser, C. M., \& Barrett C.B. 2002. Labor, liquidity, learning, conformity and smallholder technology adoption: The case of SRI in Madagascar. Cornell University Dept. of Applied Economics and Management. Working Paper. Cornell University. Web site https://papers.ssrn.com/sol3/papers.cfm?abstract id=328662.

National University of Laos (NUOL) 2018. Using the Research Discussion Tool: ASEM/2014/052: Report activities January-June 2018. Web site https://sites.google.com/view/acrtechnologyadoption/project-reports 
Ndagi, A. H., Kolo, I., NYabagi, A. A., \& Garba, Y. 2016. Adoption of production technologies by lowland rice farmers in Lavun local government areas of Niger State, Nigeria. International Journal of Agricultural Extension, 4, 49-56.

Nederlof, E. S., Roling, N., \& Huis, A. 2007. Pathway for agricultural science impact in West Africa: Lessons from the convergence of sciences programme. International Journal of Agricultural Sustainability, 5, 247-264.

Neill, S. P., \& Lee. D. R. 2001. Explaining the adoption and disadoption of sustainable agriculture: The case of cover crops in Northern Honduras. Economic Development and Cultural Change, 49, 793-817.

Newby, J. C., Manivong, V., \& Cramb, R. A. 2013. Intensification of lowland rice-based farming systems in Laos in the context of diversified rural livelihoods. 57th AARES Annual Conference, 2013 Sydney, Australia.

Orr, A. 2012. Why were so many social scientists wrong about the green revolution? Learning from Bangladesh. J. Dev. Stud., 48, 1565-1586.

Pannell, D. J., Marshall, G. R., Barr, N., Curtis, A., Vanclay, F., \& Wilkinson, R. 2006. Understanding and promoting adoption of conservation practices by rural landholders. Australian Journal of Experimental Agriculture, 46, 1407-1424.

Pattanayak, S. K., Mercer, D.E. Sills, E., \& Yang, J.C. 2003. Taking stock of agroforestry adoption studies. Agroforestry Systems, 57, 173-186.

Pereira, L., Karpouzoglou, T., Doshi, S. A., \& Frantzeskaki, N. 2015. Organising a safe space for navigating social-ecological transformations to sustainability. International Journal of Environmental Research and Public Health, 12, 6027-6044.

Pereira, M. A., Fairweather, J. R., Woodford, K. B., \& Nuthall, P. L. 2016. Assessing the diversity of values and goals amongst Brazilian commercial-scale progressive beef farmers using Qmethodology. Agricultural Systems, 1-8.

Philp, J. N. M., Vance, W., Bell, R. W., Chhay, T., Boyd, D., Phimphachanhvongsod, V., \& Denton. M. D. 2019. Forage options to sustainably intensify smallholder farming systems on tropical sandy soils. A review. Agronomy for Sustainable Development, 39, 30. 
Pimhidzai, O., Fenton, N., Souksavath, P., \& Sisoulath, V. 2014. Poverty Profile in Lao PDR. Poverty Report for the Lao consumption and expenditure survey 2012-2013. In: World Bank. (ed.). Vientiane, Laos: Ministry of Planning and Investment, Lao Statistics Bureau.

Potter, R., Binns, T., Elliot, J., \& Smith, D. 2008. Geographies of development. An introduction to Development Studies (3rd edition). Pearson Education Limited, Essex, England.

Pretty, J. N. 1998. Capital assets and natural resource improvements: Linkages and new challenges. University of Essex, Colchester, UK., Centre for Environment and Society.

Pretty, J. N. 1995. Participatory learning for sustainable agriculture. World Development, 23, 12471263.

Ratner, B., Burnley, C., Mugisha, S., Madzudzo, E., Oeur, I., Mam, K., Rüttinger, L., Chilufya, L., \& Adriázola, P. 2018. Investing in multi-stakeholder dialogue to address natural resource competition and conflict. Development in Practice, 28, 799-812.

Roberts, M. 2015. Understanding farmer decision making in Northern Lao PDR. Culture, Agriculture, Food and Environment, 37, 14-27.

Rogers, E.M. 2003. Diffusion of innovations, 5th ed. New York: Free Press.

Roth, C., \& Grunbuhel, C. 2012. Developing multi-scale adaptation strategies: A case study for Farming Communities in Cambodia and Laos. Asian Journal of Environment and Disaster Management, 4, 425-446.

Sacklokham, S., Larson, S., Alexander, K., \& Khounsy, B. 2017. Can the Lao People's Democratic Republic improve food security through policies designed to improve farming production and improve smallholder farmers' livelihoods? Aspirations and reality. Ninth EuroSEAS Conference, University of Oxford, 16-18 August, 2017. Book of Abstracts. Web site http://www.euroseas.org/

Sanders, J. H., Shapiro, B. I., \& Ramaswamy, S. 1996. The economics of agricultural technology in semi-arid sub-Saharan Africa. The Johns Hopkins Studies in Development. Baltimore, MD: The Johns Hopkins University Press.

Scoones, I. 2009. Livelihoods perspectives and rural development. The Journal of Peasant Studies, 36, 171-196. 
Scoones, I., Stirling, A., Abrol, D., Atela, J., Charli-Joseph, L., Eakin, H., Ely, A., Olsson, P., Pereira, L., Priya, R., Van Zwanenberg, P., \& Yang, L. 2018. Transformations to sustainability. STEPS Working Paper 104. Brighton: STEPS Centre.

Spielman, D. J., Ekboir, J., \& Davis, K. 2009. The art and science of innovation systems inquiry: Applications to sub-saharan african agriculture. Technology in Society, 31, 399-405.

Stein, D., \& Valters, C. 2012. Understanding 'theory of change' in international development: A review of existing knowledge. Justice and Security Research Programme (JSRP) and The Asia Foundation (TAF) collaborative project : JSRP Paper 1.

Stevenson, J. R., Villoria, N., Byerlee, D., Kelley, T., \& Maredia, M. 2013. Green Revolution research saved an estimated 18 to 27 million hectares from being brought into agricultural production. Proceedings of the National Academy of Sciences, 110, 8363-8368.

Stür, W., \& Gray, G. D. 2014. Review of rice-based farming systems in mainland southeast Asia Working Paper 3. Livestock in smallholder farming systems of mainland Southeast Asia. University of Queensland Australia and International Centre for Tropical Agriculture (CIAT), Hanoi.

Sumberg, J., \& Thompson, J. 2012. Contested agronomy: agricultural research in a changing world. New York, Routledge.

Sumberg, J., Thompson, J., \& Woodhouse, P. 2013. Why agronomy in the developing world has become contentious. Agriculture and Human Values, 1, 71-83.

Tegengne, Y. 2017. Factors affecting adoption of legume technologies and its impact on income of farmers: The Case of Sinana and Ginir Woredas of Bale Zone. MSc in Agriculture (Agricultural Economics) MSc dissertation: Haramaya University, Haramaya

Thongphanh, D. 2004. Does decentralisation meet the needs of local people?: Implementing land and forestland allocation in two local communities, Lao PDR. Tenth Conference of the International Association for the Study of Common Property. Oaxaca, Mexico.

Thornton, P. K., Schuetz, T., Förch, W., Cramer, L., Abreu, D., Vermeulen, S., \& Campbell, B. M. 2017. Responding to global change: A theory of change approach to making agricultural research for development outcome-based. Agricultural Systems, 152, 145-153.

United Nations. 2018. LDC Identification Criteria \& Indicators. Web site https://www.un.org/development/desa/dpad/least-developed-country-category/ldc-criteria.html. 
United Nations. 2019. Least Developed Countries Category. CDP Secretariat Visists Lao People's Democratic Republic. Web site https://www.un.org/development/desa/dpad/theme/leastdeveloped-countries-category/

van Kerkhoff, L. E., \& Lebel, L. 2015. Coproductive capacities: rethinking science-governance relations in a diverse world. Ecol. Soc., 20(1), Art.14.

Vogel, C., Moser, S. C., Kasperson, R. E., \& Dabelko, G. D. 2007. Linking vulnerability, adaptation, and resilience science to practice: Pathways, players, and partnerships. Global Environmental Change, 17, 349-364.

Vogel, I. 2012. Review of the use of 'theory of change' in international development. London: Department for International Development.

Vosti, S., \& Witcover, J. 1996. Slash-and-burn agriculture- household perspectives. Agriculture, Ecosystems and Environment, 58, 23-38.

Workman, D. 2019. Rice exports by country. Website http://www.worldstopexports.com/rice-exportscountryl.

World Bank. 2012. Agricultural Innovations Systems - An Investment Source Book. In: The World Bank (ed.). Washington D.C. .

Wossen, T., Abdoulaye, T., Alene, A., Haile, M. G., Feleke, S., Olanrewajub, A., \& Manyong, V. 2017. Impacts of extension access and cooperative membership on technology adoption and household welfare. Journal of Rural Studies, 54, 223-233.

\section{Annex A Research Discussion Tool}

\begin{tabular}{|c|c|c|c|c|c|}
\hline Date: & & & & & \\
\hline Project Nam & and Number: & & & & \\
\hline Project Fund & g Institution and Research & & & & \\
\hline Project Desc & tion: & & & & \\
\hline Main Project & bjectives: & & & & \\
\hline Key Stakeho & ers & & & & \\
\hline Discussion G & up Details & & & & \\
\hline Name & & Institution & & & \\
\hline $\begin{array}{l}\text { Which of the } \\
\text { important ite }\end{array}$ & $\begin{array}{l}\text { llowing items are important } \\
\text { now? }\end{array}$ & Low) for th & par & ular $\mathrm{p}$ & hat is the status of the \\
\hline & Eleme & er Product & on S & tem & \\
\hline Importance & Itom & & atus & & Commont/Aation \\
\hline HM L & Item & $x$ & $?$ & $\checkmark$ & comment/Action \\
\hline & 1. Biophysical & & & & \\
\hline & Soil & & & & \\
\hline & Water & & & & \\
\hline
\end{tabular}




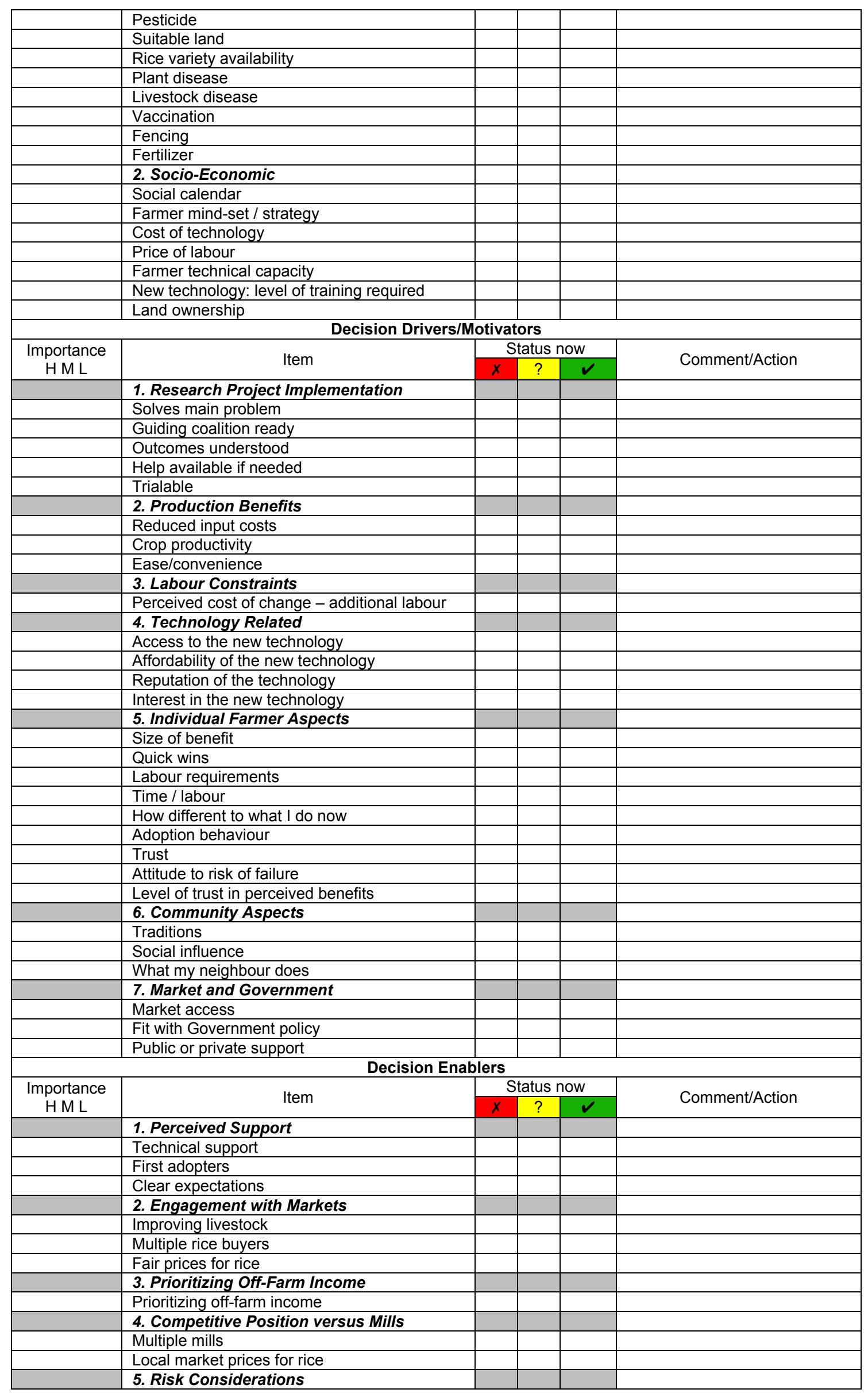




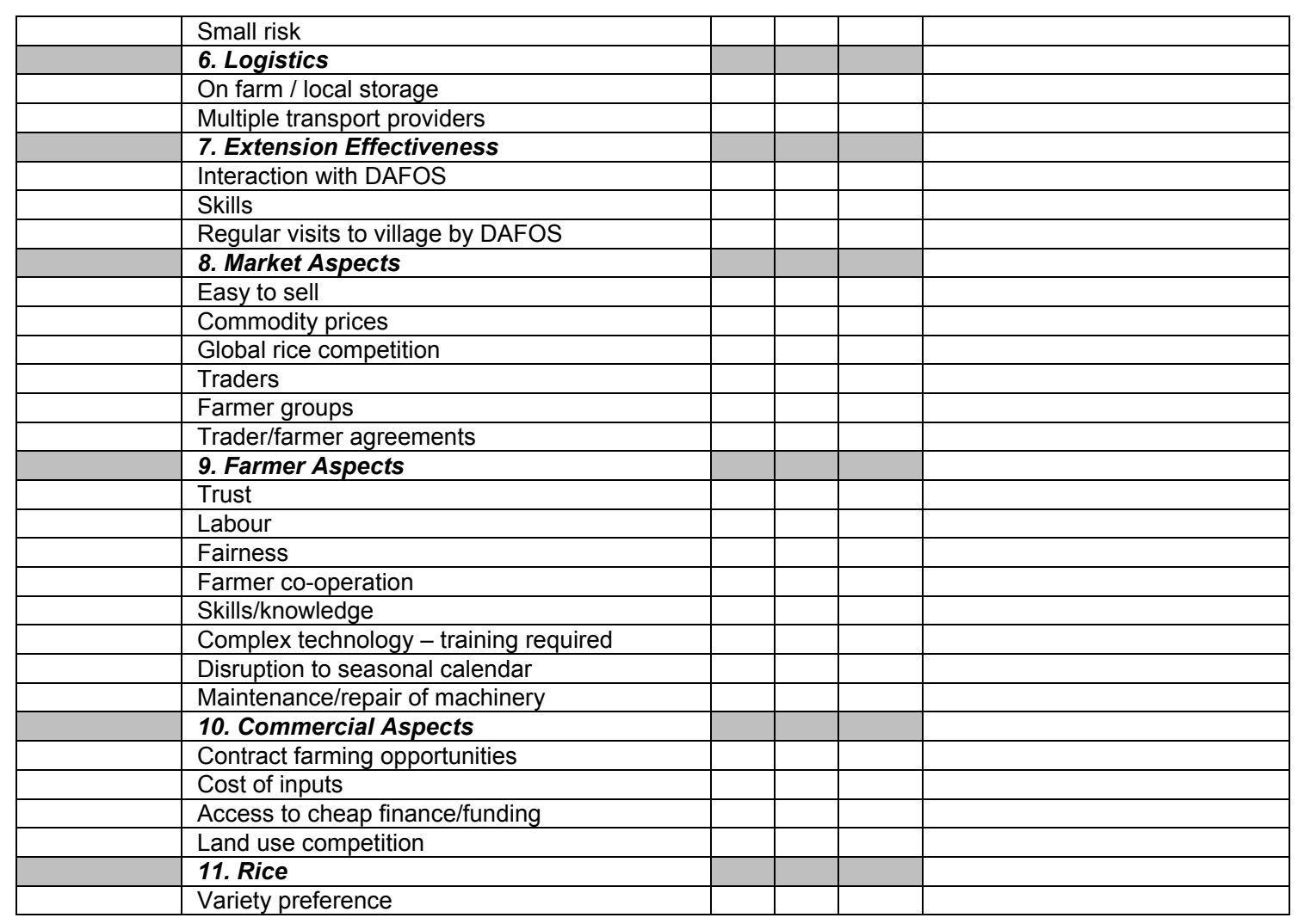

Are there any additional items specific for this particular research project?

\begin{tabular}{|l|l|}
\hline Example & 'production calendar' for main crops
\end{tabular} 